Why Executive Power Centralizes Government

\author{
Samuel H. Baker \\ College of William and Mary
}

College of William and Mary

Department of Economics

Working Paper Number 9

November 2004

Revised May 2005

I thank Donald E. Campbell, Carlilse E. Moody, James M. Poterba, William M. Rodgers, two referees, and the editor of this Review for helpful comments. The usual disclaimer applies. 
COLLEGE OF WILLIAM AND MARY

DEPARTMENT OF ECONOMICS

WORKING PAPER \# 9

November 2004, revised May 2005

\title{
Why Executive Power Centralizes Government
}

\begin{abstract}
This paper examines the effects of political parties, executive power and efficiency on federal structure. It proposes and tests a model of federalism in which different levels of veto power can lead to varying degrees of centralization in the provision of central and local governmental services when executive and legislative branches have disparate preferences over which level should provide services. Results for the US (1982-1992) find state and local spending centralizes with increased veto power because, absent offsetting political party advocacy for decentralization, central government spending interests dominate local government spending interests.
\end{abstract}

JEL Classification: H1 1

Keywords: federalism, centralization, political parties, executive power, veto

Samuel H. Baker

Department of Economics

College of William and Mary

P.O. Box 8795

Williamsburg, VA 23187-8795

shabake@wm.edu 


\section{INTRODUCTION}

A number of recent developments have drawn renewed attention to the political economy of federalism. There are efforts to write new constitutions in numerous countries from Britain to South Africa to Russia, initiatives to devolve federal policy responsibilities in such dissimilar economies as China and the United States, and changes in the institutions regulating economic policymaking in eastern and Western Europe. The beginning of the current debate is marked by the framing of the US Constitution and the struggle between Federalists and Anti-federalists. James Madison and other Federalists advocated a compound republic including a central government capable of acting counter to local interests. Anti-federalists supported Charles Louis Montesquieu's earlier vision for a decentralized confederate republic composed of sovereign states. The clash between the compound and confederate models of government remains at the center of the controversies over the design of federalist constitutions. ${ }^{1}$

The traditional literature on optimal federalism addresses the problem of finding the efficient allocation of economic responsibilities among levels of government in a federal system. However, absent a social planner choosing policies to maximize a well-defined welfare function, a political economy model is required to understand how preferences and the political system interact to generate differences in federal structure. Although one would expect considerations of efficiency to influence federal 
expenditure patterns, these patterns may also vary with the extent to which political parties reflect the historic tension between the compound and confederate conceptions of government as well as the constitutional powers granted to the executive branch.

The experience in the U.S. at the state level provides a laboratory for the analysis of constitutional change. Concerned about the separation of powers, architects of constitutions debated the appropriate range of governors' veto authority. Prior to the Civil War, states followed the Federal example and adopted constitutions granting governors the all-or-nothing veto, allowing executives to accept or reject legislatures' spending bills. The line-item veto spread during the remainder of nineteenth century, empowering governors to veto any item in a bill. As Benjamin (1982) notes, this was a period of general concern about the ascendancy of legislative power. The rapid diffusion of the lineitem veto often left its exact constitutional limits hazily defined. Some legislatures began to join several otherwise unrelated appropriations into one budget "item" to place them beyond the reach of the governor. Beginning with Pennsylvania in 1885, governors used an item-reduction veto to constrain such bundling. Supreme courts in Pennsylvania and some other states sustained executive authority to reduce spending on any item.

There is a general expectation in the U.S. that the line-item veto at the Federal level will limit special interest legislation, helping to "bring government under control." However, theoretical 
and empirical work finds no systematic effect of enhanced veto authority on spending. Much of the theoretical work serves to dispel the common misconception enhanced veto power restrains spending. ${ }^{2}$ Empirical research focuses on the effect of the lineitem veto on state governmental spending in the U.S. ${ }^{3}$ Several papers depart from this emphasis, but find no evidence of effects of enhanced veto authority on other outcomes. ${ }^{4}$ However, one recent papers find effects of enhanced veto power on the ability of the governor to obtain his proposed budget and on the centralization of state and local governmental expenditures. ${ }^{5}$ And, Baker (2000) finds the line-item and item-reduction vetoes increase state governments' share of state and local spending and employment in fiscal year 1987. Here I provide in section 2 a more general model incorporating the effects of political parties. And, Section 3 supplies empirical tests for the US during an expanded time period chosen to test for the effect of the Republican Party's recent advocacy of decentralization. The broadened time period is combined with the introduction of several additional control variables.

This paper helps to explain further the stakes in the veto debate. It proposes a model of a federalist system where the historical strains between the compound and confederate models appear as rivalry between central and local governmental spending interests. Executive power and the politics of decentralization impact federal spending structure, redistributing between central 
and local authorities the advantages derived from serving their respective spending interests. The proposed model of federal spending combines components from Carter and Schap's $(1987,1990)$ contributions on veto authority with Becker's (1983, 1985) work on competition among pressure groups for political influence. The model depicts the allocation of responsibilities among different levels of government as the consequence of three forces: veto power, efficiency considerations, and executive/legislative preferences. Becker's analysis implies competition among pressure groups makes efficient assignment of responsibilities more likely than inefficient ones. Preferences may be either intrinsic to the two branches or partisan-based. In the former case the executive inherently prefers more central governmental spending than a geographically based legislature more responsive to local governments' demands for decentralized spending. In the latter case the political affiliation of the executive and legislature drive preferences. Empirical evidence for the U.S. indicates all three forces impact expenditure centralization.

\section{THEORETICAL MODEL}

The model is located at the intersection of the literature on veto power as an institutional constraint and optimal federalism. Assume a central government's budget decision on a spending bill determines local spending for a service by providing intergovernmental transfers or interchanging central and local 
provision. Thereby, the service may be provided jointly or at either level of government. Consider an executive (E) facing a legislature (L) as a single actor. ${ }^{6}$ The decision of $\mathrm{E}$ and $\mathrm{L}$ determines a budget with two elements, central governmental spending (CS) and local governmental spending (LS). ${ }^{7}$

In Figure 1 the politically optimal values of CENT and LS for $E$ and $L$ are $x_{E}$ and $x_{L} \cdot E$ and $L$ both prefer CS and $L S$ above reversion levels. However, E disproportionately favors CS, and L disproportionately supports LS. Such preferences may either be inherently determined by spending pressures on their respective offices, or arise from political party affiliation. Consider first the case where these preferences are intrinsic. L's preference peak may lie southeast of E's because L disproportionately serves geographically dispersed spending interests most easily exerting their influence on local governments. Such interests include local governmental employees and contractors providing the service as well as customers.

In Figure 1 assume the preferences of $E$ and $L$ are such that indifference curves are concentric circles about the actors' most preferred budgets. Following Carter and Schap (1987, 1990), in Figure $1 \mathrm{x}_{\circ}$ represents the default levels to which $\mathrm{CS}$ and $\mathrm{LS}$ revert if the legislature does not pass the bill. With the all-ornothing veto $\mathrm{E}$ may either accept a legislated budget bill or exercise a veto to the reversion level, $x_{0}$. The executive exercises a veto if $x_{0}$ is preferred to the legislated budget. 
Thus, examining the executive's indifference curve passing through $\mathrm{x}_{0}$, we see that $\mathrm{E}$ exercises an all-or-nothing veto against legislated budgets outside this circle. Assuming $L$ knows what action $E$ will take on any submitted bill and utilizes that information strategically, $L$ chooses its most preferred budget from the set of budgets immune to the all-or-nothing veto and passes $x_{a}$, the closest point in this set to $x_{L}$. The point $x_{a}$ is a Stackelberg (1934) equilibrium, having the distinguishing characteristic that one player (L) takes action first.

Given the line-item veto, the executive may either accept a legislated budget bill, veto either budget item (CS or LS) to its reversion level, or veto both to the reversion levels. Contained in the circle in Figure 1 is the rectangle having $x_{\circ}$ as one of its corners. Given any legislative budget proposal east of the rectangle, there is a point preferred by $\mathrm{E}$ and reachable by veto on the western boundary of the rectangle. $\mathrm{L}$, again anticipating the action of $\mathrm{E}$, chooses its most preferred budget from the set of budgets escaping the line-item veto and passes $x_{i}$ lying closest to $\mathrm{x}_{\mathrm{L}}$. With the item-reduction veto, $\mathrm{E}$ may either accept the legislative spending bill, veto totally to $x_{0}$, or reduce either item to as little as its reversion level. In Figure 1, E will now veto any proposed $\mathrm{LS}>\mathrm{LS}_{1}$ down to $\mathrm{LS}_{1}$. L's best combination of CS and $\mathrm{LS}_{1}$ escaping veto is $\left(\mathrm{CS}_{1}, \mathrm{LS}_{1}\right)$ at $\mathrm{x}_{\mathrm{r}}$.

As Carter and Schap (1987) point out, veto power varies directly with the permissiveness of the veto rule: greater veto 
power in Figure 1 results in higher levels of utility for $\mathrm{E}$ and lower levels for L. However, the effect of veto power on expenditure centralization (e.g., the ratio of CS to LS) is less clear. The budget $x_{r}$ has a higher ratio of central spending to local spending than $x_{i}$. However, $x_{i}$ does not in general have a higher ratio than $\mathrm{x}_{\mathrm{a}}$. Which of these two points has a higher ratio depends on where these two points lie relative to the origin. As one can see, if the intercept is above the origin (as in Figure 1), the ratio is higher at $x_{i} ;$ if the intercept is below the origin, the ratio is higher at $x_{a}$. The same qualification applies to the $\mathrm{x}_{\mathrm{r}}$ versus $\mathrm{x}_{\mathrm{a}}$ comparison.

Next, let political affiliation determine the preferences of $E$ and $L$ in a two party setting with control of the two branches split. In the U.S. in recent years the Republican Party championed decentralization. With partisan based preferences, the results above now hold for a Democratic governor facing a Republican legislature. When the executive relatively favors LS (he is Republican and the legislature is Democratic) and thus the definitions of the coordinates in Figure 1 are reversed, decentralization now increases when the item-reduction veto replaces the line-item veto. If instead of splitting branches, Republicans (Democrats) gain control of both branches and thereby $\mathrm{E}$ and $\mathrm{L}$ have identical preferences, centralization decreases (increases) .

The politically optimal points $x_{\mathrm{E}}$ and $\mathrm{x}_{\mathrm{L}}$, and thus the 
combination of $\mathrm{CS}$ and LS resulting from a particular veto rule, reflect also efficiencies available from optimal federalism. Becker's (1983) model implies policies increasing efficiency are more likely to be adopted than policies decreasing efficiency. ${ }^{8}$ Applying his model here, where there is greater potential governmental failure in terms of a large inefficiency in federal structure, there is greater pressure for optimal federal structure. As a result, $\mathrm{x}_{\mathrm{E}}$ and $\mathrm{x}_{\mathrm{L}}$ reflect both political support for optimal federalism as well as the political pressures arising from geographically based interests and partisan preferences.

Assume increases in population yield local governments economies of scale so that all or some portion of a service becomes less costly than central provision. A proposal is made to substitute an equal amount of local for central production financed by an intergovernmental transfer equal the amount being spent on more costly central production. Applying Becker's (1983) model, the net subsidy above cost to local governments yields an advantage of local spending interests to exert more pressure than central spending interests of the same size, efficiency of organization, and political appeal. In his model inefficient policies not only lead to relatively less pressure from groups subsidized by inefficiency, but also encourage pressure from taxpayers for efficiency. Thus, in Figure $1 \mathrm{x}_{\mathrm{E}}$ and $\mathrm{x}_{\mathrm{L}}$ and the equilibrium induced by a given veto rule shift to the southeast.

Alternatively, consider a decrease in the land area of a 
central government and its implications for optimal federal structure. Hochman, Pines, and Thisse (1995) demonstrate that space matters in designing the optimal provision of local public goods. In their model market areas of different local public goods overlap. Since the beneficiaries of local governmental services require space in which to live, individuals are spread out geographically, and services are provided at locations different from residences. Thus, the authors focus on the role of transportation costs to the local facility providing a good, or on the decreasing level of service with distance between the beneficiaries' residential location and the public facility. They show that optimal governmental structure can be achieved within large territorial based governments, matching those who receive the benefits of a collective good with those who pay for it. Casting their large government as the central government here, as a geographic area decreases, overlapping market areas for a services are more likely to fit optimally into one central government. The Becker (1983) framework implies that such increased efficiency of central provision leads to political pressures shifting to the northwest in Figure 1 the equilibria resulting from veto regimes.

The political pressures for central and local provision also vary with factors underlying the demands for services. These factors include the level and distribution of income as well as demographics. Such demands create political pressures to serve 
certain groups, as well as political support to provide services within an optimal federal structure. Consider the impact of rising income on federal structure. If the income elasticity of demand for the locally provided service exceeds that for central provision, political pressures move provision toward decentralization. For example, if there exists a decreasing level of service with the distance between beneficiaries' residential locations and a public facility, then rising income may increase the demand for accessibility, leading to greater local provision. The disadvantage of local provision is the possibility of higher transaction costs, as each locality spends resources choosing its service characteristics. If these costs offset the benefits of adapting to local tastes, then rising income can lead to a disproportionate increase in central production in deconcentrated facilities.

What about the impact of the number of poor on the provision of redistributional services? Becker (1985) considers the following scenario. As the number of poor increases, they may tend to out-vote the middle class and rich and tax away their wealth. However, a larger number of poor face two political handicaps. Larger groups face greater difficulties controlling free riding and shirking. And, political support for greater redistribution withers away with the rising excess burden of taxation on the middle and rich class. Thus, a rising number of poor may increase, decrease, or leave unchanged redistribution. 
Redistributional policies are the result of the influence of political pressures arising from recipients (including the poor, young, and old) and nonrecipients. The value nonrecipients place on redistribution may depend both on their own characteristics and on the characteristics of the recipients. Cutler, Elmendorf, and Zeckhauser (1993) point out that nonrecipients may care about recipients in an "even-handed" way, where concern for recipients depends on their needs but not their identities. They also argue that nonrecipients may care about the consumption of recipients in discriminatory fashion, where concern about recipients depends on their similarity to nonrecipients. In the discriminatory model nonrecipients place more weight on transfers to people of their own ethnicity or race than to others. While any model of governmental redistribution would allow for responses varying with the demographic characteristics of the recipient population, the discriminatory model also has the degree of demographic fragmentation or diversity as a determinant of transfer spending. In the model here, with discriminatory nonrecipient preferences an increase in demographic diversity decreases redistributional services at the central and local levels. The resulting change in expenditure centralization depends on the relative size of these effects. With even-handed preferences an increase in demographic fragmentation has no effect.

\section{EMPIRICAL MODEL}


Applying the theoretical model in section 2, state centralization (CENT) in providing state and local services in the U.S. is:

CENT = CENT(ITEM, ITEMRED, RGOVDLEG, DGOVRLEG, RGOVRLEG, DGOVDLEG, POP, AREA, INC, POV, DEMFRAG, OLD, YOUNG, URBAN )

where:

CENT = a state share of total state and local general expenditure (after transfers among all governments)

ITEM = a dummy variable equal to one if the state's governor has the line-item veto, zero otherwise

ITEMRED = one if the governor has the item-reduction veto, zero otherwise

RGOVDLEG = one if the governor is a Republican and both houses of the legislature are controlled by the Democrats, zero otherwise

DGOVRLEG = one if the governor is a Democrat and both houses of the legislature are controlled by Republicans, zero otherwise

RGOVRLEG = one with Republican control of both branches, zero otherwise

DGOVDLEG = one with Democratic control of both branches, zero otherwise

POP $\quad$ state population

AREA = state land area 


$\begin{array}{ll}\text { INC }= & \text { personal income per capita } \\ \text { POV } & \text { fraction of persons in poverty, proxied by a state's } \\ & \text { labor force participation rate (LABPART) } \\ \text { DEMFRAG = } & \text { demographic fragmentation } \\ \text { OLD }= & \text { fraction of population } 65 \text { years and older } \\ \text { YOUNG }= & \text { fraction of population } 17 \text { years and younger } \\ \text { URBAN }= & \text { fraction of population living in urban areas. }\end{array}$

CENT, the most common measure of the extent to which a federal system is centralized, is based on general expenditure by the final disbursing level of government, after intergovernmental transfers. ${ }^{9}$ General expenditure includes all spending other than that on utilities, retirement or other insurance trusts.

In section $2 \mathrm{CENT}$ is the result of the veto rule and actors' preferences. With preferences of $\mathrm{E}$ and $\mathrm{L}$ determined intrinsically by spending pressures on their respective offices, ITEMRED in equation (1) increases CENT more than ITEM. The excluded class is the all-or-nothing veto. With equation (1) including RGOVDLEG and DGOVRLEG for split control of branches and RGOVRLEG and DGOVDLEG for unitary control, the omitted class includes divided control of the legislature and incorporates the effect of the preferences of the average governor facing the average divided legislature. Thus, compared to the omitted class, the mutually reinforcing effects of unitary control (RGOVRLEG and DGOVDLEG) lead unambiguously to changes in CENT in the direction of party preferences. The split 
party control variables (RGOVDLEG, DGOVRLEG) may decrease or increase CENT.

In section 2, changes in other variables have effects through preferences of $\mathrm{E}$ and $\mathrm{L}$ as differential political pressures arise from central and local spending interests, including the stakeholders in optimality. Ceteris paribus, a rise in POP decreases CENT as local provision becomes more attractive with scale economies. Following Hochman, Pines, and Thisse (1995), increases in AREA in equation (1) raise the likelihood market areas for public goods fit optimally into local jurisdictions, decreasing CENT. The level and distribution of income also impacts CENT. The effect of a rise in INC on CENT depends both on the income elasticity of demand for each state and local service as well as the composition of services provided by each level of government. A higher poverty rate increases CENT due to higher state spending under the Aid to Families with Dependent Children and Medicaid programs. I proxy poverty inversely using state labor force participation rate (LABPART) as an inverse proxy. When this proxy was substituted for the share of a state's population that is below the poverty line, it provided enhanced statistical significance without altering other results. I employ an approach used by Luttmer (1998) to measure demographic fragmentation (DEMFRAG), who focuses on racial heterogeneity, measured by the probability that two randomly selected persons belong to different racial groups (black and nonblack). This probability is (DEMFRAG = 
1 - $\left.(\text { fraction black })^{2}-(\text { fraction nonblack) })^{2}\right)$ With a disproportionate share of black recipients, an increase in DEMFRAG in equation (1) decreases the demand for redistribution by nonblacks with discriminatory preferences. ${ }^{10}$ Such effects may impact CENT by differentially affecting the redistributional components of CS and LS. If nonrecipients preferences are "even handed," DEMFRAG has no effect on CENT.

Equation (1) includes three additional demographic variables. Increases in OLD raises the proportion of a state's population receiving Federal transfers (Social Security and Medicare) and could decrease CENT by reducing political pressure (and substituting) for transfers at the state and local level, or increases in OLD could alter the political demands for state and local services in other ways, increasing or decreasing CENT. An increase in YOUNG, a focus of both state and local governments, reduces CENT if it results in disproportionate pressures for locally provided services for the young. A rising fraction of the population living in urban areas decreases CENT if it generates disproportionate political pressures for local services.

Beginning in 1981, the national Republican party pushed for decentralization of government, followed by the "new federalism" initiative of the Reagan administration in 1982. To test for the effects political party affiliation on decentralization at the state level, I pool available Census of Governments data for fiscal years 1982, 1987 and 1992. I use a classification of veto 
authority provided by Carter and Schap (1990, 116). Their grouping eliminates six states (HI, MD, NB, NY, NC, and WV) that cannot be clearly categorized without error. Within this six-state group, three states (HI, MD, NB) have a hybrid veto form, four (MD, NB, NY, WV) limit the legislature's power to change the governor's budget, and one (NC) has no veto. The remaining forty-four states serve as the sample here, of which twenty-six states have the item-veto, twelve the item-reduction veto, and six states the allor-nothing veto. Data sources appear in Table 1, and summary statistics for variables are in Table 2 .

In section 2 central spending is determined by executive and legislative preferences in the presence of a veto rule. To account for such interactive effects, I estimate a log-log form of equation (1). To control for any additional geographic variation in CENT not captured by the independent variables, I utilize dummy variables for the Census Division's regions. The Mountain region is the excluded class.

Ordinary least squares estimates of equation (1) appear in Table 3. Using White's (1980) test for heteroskedasticty, the null hypothesis of homoskedastic errors is rejected at the 5 percent level of significance. Results are based on White's consistent estimator of the parameter covariance matrix. ITEM and ITEMRED have positive impacts on CENT, statistically significant effects at the 1 percent level. ${ }^{11}$ The hypothesis the coefficients of ITEM and ITEMRED are equal is rejected at the 1 percent level. 
Independent of political affiliation, governors appear to use enhanced veto power to centralize spending.

A question of interpretation arises in considering how to view the correlations between state CENT and enhanced veto power. It is possible such correlations simply reflect correlations involving CENT, enhanced veto authority, and an omitted third variable - voter tastes for CENT. Voters in some jurisdictions may be more inclined to have centrally provided services, and these voters may also be more inclined to support constitutional provisions giving governors enhanced veto authority to run a large centralized government. Thus, the causal link between enhanced veto power and CENT may be spurious.

Clearly, there are cases where the determinants of institutional innovations have been successfully modeled. For example, Alm, McKee, and Skidmore (1993) focus on the introduction of state lotteries, examining the factors affecting the likelihood a state will enact a lottery. This probability is a function of economic, fiscal, demographic, and political factors. Also, Alm and Skidmore (1999) estimate the chances of passing a tax expenditure limitation (TEL) in a state election. This probability is a function of specific features of the TEL as well as fiscal, demographic, and political variables.

It is difficult to provide definitive evidence that supports or rejects the view that enhanced veto authority in the model here is endogenous. One way to develop such evidence would be to 
include controls for voter preferences. INC and other variables serve as such controls in equation (1). Another way to address the possible endogeneity of veto power is to draw on the history of these institutions. As discussed in the introduction of this paper, the diffusion of the line-item veto occurred largely in the late nineteenth century. Also, the item-reduction veto is the product of court interpretations of the constitutional powers granted under the line-item veto. Whether the presence of these veto powers and CENT systematically reflect the preferences of state residents during the late twentieth century is an open question. Clearly, the more difficult it is to make changes in state constitutional law, the more valuable the cross-state variation is in identifying the effect of these institutions on centralization. While the potential endogeneity of veto institutions warrants some caution in drawing conclusions, the evidence here suggests that enhanced veto authority increases central spending. ${ }^{12}$

Because pressures from spending interests (e.g., those receiving and paying for a service and those employed in its provision) empirically cannot be distinguished from pressures for optimality (e.g., the balancing of the benefits and costs of spending), these results imply nothing about optimality. In section 2, CENT is the result of the veto rule as well as executive and legislative preferences, with tastes reflecting the pressures from central and local spending interests as well as 
political support for optimal federalism. Thus, for example, enhanced veto power and increased CENT may go along with increased efficiency, substituting more efficient state provision for state transfers financing local spending of the "pork barrel" variety. Alternatively, increased CENT be associated with decreased efficiency, matching less the provision of services with varying geographic tastes.

In Table 3 DGOVRLEG has a statistically significant negative impact. This result is consistent with interest group pressure for decentralization manifesting itself in part through Republican control of the some legislatures. However, RGOVRLEG is statistically insignificant: when Republicans extend their control to both branches, they do not decentralize as advertised. With Republican control of both branches the results are no different from those obtained for the omitted variable class (or the average governor facing the average split legislature). Such results are consistent with Republicans behaving strategically, pursuing decentralization with control of only the legislature to limit the political gains a Democratic governor can obtain from centralizing spending but finding centralization relatively attractive themselves with control of both branches. However, things are not as bad for Republicans as, in the words of the alligator in the comic strip Pogo, "we have met the enemy and they is us." With Democratic control of both branches centralization increases. Focusing on other coefficients statistically significant at 
the 5 percent level, POP has a negative impact on CENT: increases in POP and scale economies in providing local services make local provision more attractive. Increases in AREA decrease CENT, raising the likelihood market areas for public goods fit optimally into local jurisdictions. ${ }^{13}$ Decreases in LABPART and more poverty result in increased centralization due to higher state spending under the Aid to Families with Dependent Children and Medicaid programs. These results are consistent with the poor effectively demanding more centralization because the central government can be more redistributive when the rich more easily escape redistribution with decentralization). The statistically negative coefficient on DEMFRAG is consistent with rising racial heterogeneity decreasing nonrecipients' discriminatory demands for redistribution more at the state than the local level. Apparently, discriminatory preferences for spending at the state level dominate the role of such preferences at the local level in determining the politically optimal positions for the governor and legislature. ${ }^{14}$ URBAN has a negative effect on CENT, increasing political pressure for local service provision. The hypothesis the coefficients of the regional dummies equal zero is rejected at 1 percent level using a Wald statistic. The 1992 year dummy is positive and significant.

\section{CONCLUSIONS}

Because the American press has focused more on rivalry 
between political parties than competition between state and local spending interests, results here may at first seem surprising • Republicans at the state level do not appear completely constrained by their party's recently announced position advocating decentralization of government. Although Democrats centralize when in control of both branches, Republicans decentralize only when serving as the opposition party in the legislature. When in control of both branches, Republicans have no impact on centralization. Such results are consistent with a strategic element in Republican behavior: with control of the legislature as the opposition party, decentralize to appeal to local spending interests and limit the political gains a Democratic governor obtains from centralizing spending, while with control of both branches, tradeoff political losses resulting from embracing less decentralization for political gains from centralization.

Independent of political party effects, governors use enhanced veto power to centralize expenditures, achieving with the item-reduction veto greater centralization than with the line-item veto. And, legislatures use the opportunity offered by diminished veto power to decentralize spending. These results yield some clues to why the executive branch centralizes government. Executive power centralizes because the political pressures behind state and local spending interests have a more consistent, forceful impact than political party affiliation. Absent 


systematic offsetting political party opposition to
centralization, more fundamental and historic pressures on the
branches dominate. The competition between the executive and
legislative branches, pitting central against local spending
interests, reflects enduring elements in the debate between the
compound federal model of government and the confederate
independent city-state alternative.




\section{ENDNOTES}

1. See Inman and Rubinfield (1997) for a further discussion of the compound and confederate models.

2 Carter and Schap (1987) demonstrate, even when the executive systematically prefers less spending than legislators, a switch from an all-or-nothing veto to a line-item veto can decrease or increase budget levels. Similarly, Dearden and Husted (1990) show an increase in authority from the line-item to the item-reduction veto may lead to more spending, leaving the executive further from his most preferred budget.

3. Abrams and Dougan (1986) and Nice (1988) conclude the line-item veto authority has no systematic impact on spending. Holtz-Eakin (1988) finds the line-item veto restrains spending in the short run, an effect most pronounced when a governor encounters a legislature dominated by the opposing political party without the votes to override. However, the line-item veto has no effect on long-run variations in budgets, even allowing for political circumstances. Alm and Evers (1991) conclude the lineitem veto has a small negative impact on spending in states where the dominant political party in the legislature differs from the governor's political party. In states where the governor and legislature share the same political affiliation, spending increases in the presence of the line-item veto.

4. Rowley, Shugart, and Tollison (1987) find the line-item 
veto does not affect the level of state borrowing. Carter and Schap (1990) conclude the line-item veto has no effect on the value of the governor's office (as proxied by campaign spending) or the incumbent's share of the two-party vote. Also, they find that the proportion of governors later elected (or nominated) to the U.S. Senate from line-item veto states is smaller than the proportion of governors without such veto authority.

5. Dearden and Husted (1993) examine the effect of the lineitem veto on the percentage difference between the final state budget and governor's original budget request. They find the lineitem veto enhances a governor's ability to obtain his or her desired budget in a state where the legislature is dominated by the governor's opposing political party, but is short of the votes necessary to override a veto.

6. Although $\mathrm{L}$ is a unitary actor by assumption here, it should be noted that social choice theorists (following the seminal contributions by Arrow (1951) and Black (1958)) have long recognized that, where there are multiple proposals, situations may arise where no alternative dominates even when individuals have consistent preferences.

7. The model here ignores additional features of the budgetary process incorporated in some of the literature cited in footnotes 2,3 , and 5 .

8. Becker's paper builds on earlier work by Olson (1965), Stigler (1971), and Peltzman (1976). 
9. As Rosen (1999) points out, if subnational spending is constrained by the central government, the centralization ratio can understate the true extent of centralization in the system. Transfers may come with "strings attached," constraining a subnational government's decision-making power. Similarly, unfunded spending mandates pose constraints. However, such constraints may also reflect lobbying efforts of subnational interests and governments to achieve their own ends. Taking a longer view, dictates from the central government can alter the composition of a subnational government's customer base. What initially may be an imposed requirement to serve a particular group may later become a source of political support from that group.

10. In 198610.9 percent of all races were poor, while 28 percent of blacks were poor (Statistical Abstract of the United States 1990 , Table 748 ).

11. It may appear paradoxical that earlier empirical work finds little effect of enhanced veto power on state expenditures while this study finds robust effects of increased veto authority on CENT. However, the results here utilize a fundamentally different dependent variable. Also, previous studies measure state expenditures including transfers to local governments while our model focuses on disbursements after transfers. Also, the work here has the advantage of a clear delineation of enhanced veto power in Carter and Schap (1990). 
12. The discussion here follows by analogy Poterba's (1994, 1996) analysis of potential endogeneity in the relation between fiscal policy and balanced budget requirements at the state level in the U.S.

13. Wallis and Oates (1988) provide an historical overview of the twentieth century evolution in the U.S. toward centralization in the provision of state and local service. Because of the availability of data over this time period, they have a more limited choice of explanatory variables. As in Table 3, they find centralization (in 1982) inversely related to land area and population. They also find centralization is positively related to population living on farms. When this variable is included in equation (1), it is statistically insignificant and has no impact on the results reported here. Reported results are also unaffected when the total number of local governments is included to capture possible diseconomies of scale.

14. Studies find effects of discriminatory preferences in the provision of both state and local services. Orr (1976) finds welfare benefits decline as states' nonwhite fraction of welfare recipients increases. Cutler, Elmendorf, and Zeckhauser (1993) find demographic characteristics such as race and age have markedly different impacts on the levels of county and state spending. Poterba (1997) finds support for public education declines when the racial compositions of beneficiaries and voters diverge. Baicker (1997) finds states, responding to mandated 
Medicaid spending, cut welfare more strongly when the population is more racially fragmented. Luttmer (1998) finds voters prefer to spend more on welfare when they are of the same race as likely recipients. Alesina, Baqir, and Easterly (1999) find shares of city spending on public goods like education and roads decrease as ethnic diversity increases. 


\section{REFERENCES}

Abrams, Burton A. and William R. Dougan. 1986. The effects of constitutional restraints on governmental spending. Public Choice 49 (2) : 101-116.

Alesina, Alberto, Reza Baqir, and William Easterly. 1999. Public goods and ethnic divisions. Quarterly Journal of Economics 114 (4) : 1243-1284

Alm, James, and Mark Evers. 1991. The item veto and state government expenditures. Public Choice 68 (1-3): 1-15.

Alm, James, Michael McKee, and Mark Skidmore. 1993. Fiscal pressures,tax competition, and the introduction of state lotteries. National Tax Journal 46 (4): 463-476.

Alm, James, and Mark Skidmore. 1999. Why do tax and expenditure limitations pass state elections? Public Finance Review 47 (5): $481-510$.

Arrow, Kenneth J. 1951. Social Choice and Individual Values. New York, NY: Wiley Press.

Baicker, Katherine. 1997. Government decision-making and the incidence of federal mandates. MIT Department of Economics working paper, Cambridge, MA.

Baker, Samuel H. 2000. Does enhanced veto power centralize spending? Public Choice 104 (1-2): 63-79.

Becker, Gary S. 1983. A theory of competition among pressure groups for political influence. Quarterly Journal of Economics 98 
(3) : 371-400.

.1985. Public policies, pressure groups, and dead weight costs. Journal of Public Economics 28 (3): 329-347.

Benjamin, Gerald. 1982. The diffusion of the governor's veto power. State Government 55: 99-105.

Black, Duncan, 1958. The Theory of Committees and Elections. Cambridge, UK: Cambridge University Press.

Carter, John R., and David Schap. 1987. Executive veto, legislative override, and structure-induced equilibrium. Public Choice 52 (3): 227-244.

- 1990. Line-item veto: Where is thy sting? Journal of Economic Perspectives 4 (Spring): 103-118.

Cutler, David M., Douglas W. Elmendorf, and Richard J. Zeckhuser. 1993. Demographic characteristics and the public bundle. Public Finance/Finances Publiques 48: 178-198.

Dearden, James A., and Thomas A. Husted. 1990. Executive budget proposals, executive veto, and uncertainty: a Comparative analysis of the budgetary process. Public Choice 65 (1): 1-19. - 1993. Do governors get what they want? An alternative examination of the line-item veto. Public Choice 77 (6): 707-723. Hochman, Oded, David Pines, and Jaques-Francois Thisse. 1995. On the optimal structure of local governments. American Economic Review 85 (5): 1224-1240.

Holtz-Eakin, Douglas. 1988. The line item veto and public sector budgets: evidence from the states. Journal of Public Economics 36 
(3) : 269-292.

Inman, Robert P., and Daniel P. Rubinfield. 1997. The political economy of federalism. In Perspectives on Public Choice. Dennis C. Mueller ed. Cambridge MA: Cambridge University Press, 73-105. Luttmer, Erzo F. P. 1998. Group loyalty and the taste for redistribution. Harvard University Department of Economics working paper, Cambridge, MA.

Olson, Mancur. 1965, The Logic of Collective Action. Cambridge, MA: Harvard University Press.

Orr, Larry L. 1976. Income transfers as a public good: An application to AFDC. American Economic Review 66 (3): 359-371. Peltzman, Sam. 1976. Toward a more general theory of regulation. Journal of Law and Economics 19 (2): 211-240.

Poterba, James M. 1994. State responses to fiscal crises: Natural experiments for studying the effects of budgetary institutions. Journal of Political Economy 102 (2): 793-821.

- 1996. Budget institutions and fiscal policy in the U.S. states. American Economic Review 86 (3): 395-400.

- 1997. Demographic structure and the political economy of public education. Journal of Policy Analysis and Management 16 (1) : 48-66.

Rosen, Harvey S. 2005. Public Finance. Boston, MA: Irwin McGraw$\mathrm{Hill}$.

Rowley, Charles K., William F. Shughart, II, and Robert D. Tollison. 1986. Interest groups and deficits. In Deficits 
Buchanan, James M., Charles K. Rowley, and Robert D. Tollison eds. New York, NY: Basil Blackwell, 263-280.

Schap, David. 1986. Executive veto and information strategy: A structure induced equilibrium analysis. American Journal of Political Science 30 (4): 755-770.

Stackelberg, Heinrich von. 1934. Marktform und Gleichgewicht. Berlin, Germany: J. Springer (translated by Alan Peacock (1952), as The Theory of the Market Economy). London, England: William Hodge.

Stigler, George J. 1971. The theory of economic regulation. Bell Journal of Economics and Management 2 (1), 3-21.

Wallis, John T. and Wallace E. Oates. 1988. Decentralization in the public sector: An empirical study of state and local government. In Fiscal Federalism, by Harvey S. Rosen, ed. Chicago, IL: University of Chicago Press. 
Samuel H. Baker is professor of economics in the Department of Economics at the College of William and Mary. He received his doctorate in economics at the University of Virginia. His research is in public finance and industrial organization. 
Table 1 - Data Sources

CENT Census of Governments, Vol. 4, No. 5 (US

Government Printing Office, various years).

ITEM, Carter and Schap (1990).

ITEMRED

RGOVDLEG, Book of the States (Lexington KY: Council of State

etc. Governments, various years).

POP WWW.census.gov/estimates/states.

AREA Statistical Abstract of the United States: 1988

(US Government Printing Office, 1989).

INC Statistical Abstract of the United States, various years.

LABPART Geographic Profile of Employment and Unemployment, US Department of Labor, various years.

DEMFRAG Current Population Reports (Bureau of the Census, US Government Printing Office); based on 1982 data from Series P-25, No. 1040-RD-1 (1989) and 1992 data from Series P-25, No. 1053 (1990); 1987 data estimated as the average of 1982 and 1992 .

OLD Statistical Abstract of the United States, various years.

YOUNG Statistical Abstract of the United States, various years.

URBAN Statistical Abstract of the United States, various years. 
Table 2 - Descriptive Statistics of the Variables

\begin{tabular}{|l|l|l|l|l|}
\hline & Mean & Std. Dev. & Minimum & Maximum \\
\hline & & & & \\
\hline CENT & .462 & .089 & .281 & .771 \\
\hline ITEM & .660 & .476 & 0 & 1 \\
\hline ITEMRED & .204 & .405 & 0 & 1 \\
\hline RGOVDLEG & .257 & .439 & 0 & 1 \\
\hline DGOVRLEG & .136 & .344 & 0 & 1 \\
\hline RGOVRLEG & .114 & .319 & 0 & 1 \\
\hline DGOVDLEG & .311 & .4645 & 0 & 1 \\
\hline POP (x1000) & 4,698 & 5,038 & 418 & 30,413 \\
\hline AREA & 75,596 & 8,940 & 1,060 & 570,835 \\
\hline INC & 17,598 & 3,109 & 11,310 & 27,150 \\
\hline LABPART & .6622 & .0420 & .517 & .838 \\
\hline DEMFRAG & .1599 & .1356 & .0048 & .4980 \\
\hline OLD & .1189 & .0227 & .031 & .184 \\
\hline YOUNG & .2206 & .0438 & .101 & .373 \\
\hline URBAN & .1599 & .1356 & .0047 & .4980 \\
\hline
\end{tabular}


Table 3 - Estimates of the Centralization Equation (1)

Variable Coefficient t-ratio

$\begin{array}{lcc}\text { ITEM } & .2064 & 4.63^{* *} \\ \text { ITEMRED } & .2618 & 5.78^{* *} \\ \text { RGOVDLEG } & .0203 & .81 \\ \text { DGOVRLEG } & -.1115 & -3.60^{* *} \\ \text { RGOVRLEG } & .0068 & .26 \\ \text { DGOVDLEG } & .0547 & 2.24^{*} \\ \text { POP } & -.1456 & -11.09^{* *} \\ \text { AREA } & -.0546 & -4.48^{* *} \\ \text { INC } & -.0891 & -.88 \\ \text { LABPART } & -.9798 & -2.06^{*} \\ \text { DEMFRAG } & -.1683 & -1.95^{*} \\ \text { OLD } & -3.1590 & -4.75^{* *} \\ \text { YOUNG } & -.0682 & -.12 \\ \text { URBAN } & -.2192 & -2.38^{*} \\ \text { NE } & .2395 & 4.02^{* *} \\ \text { MA } & .2147 & 2.96^{* *} \\ \text { ENC } & .1771 & 3.80^{* *} \\ \text { WNC } & .0573 & 1.43 \\ \text { SA } & .0733 & 1.50 \\ \text { ESC } & .0982 & 1.67 \\ \text { WSC } & .1440 & 3.40^{* *} \\ \text { PA } & .0918 & 2.69^{* *} \\ \text { YEAR87 } & .0737 & 1.33 \\ \text { YEAR92 } & .1549 & 5.39^{* *} \\ \text { COnstant } & 6.2753 & 13.29 \\ & & \\ \text { RSQ-adjusted } & .821 & \\ \text { n } & & \\ & & \\ & & \\ & & \end{array}$

* significant at the .05 level

** significant at the .01 level 


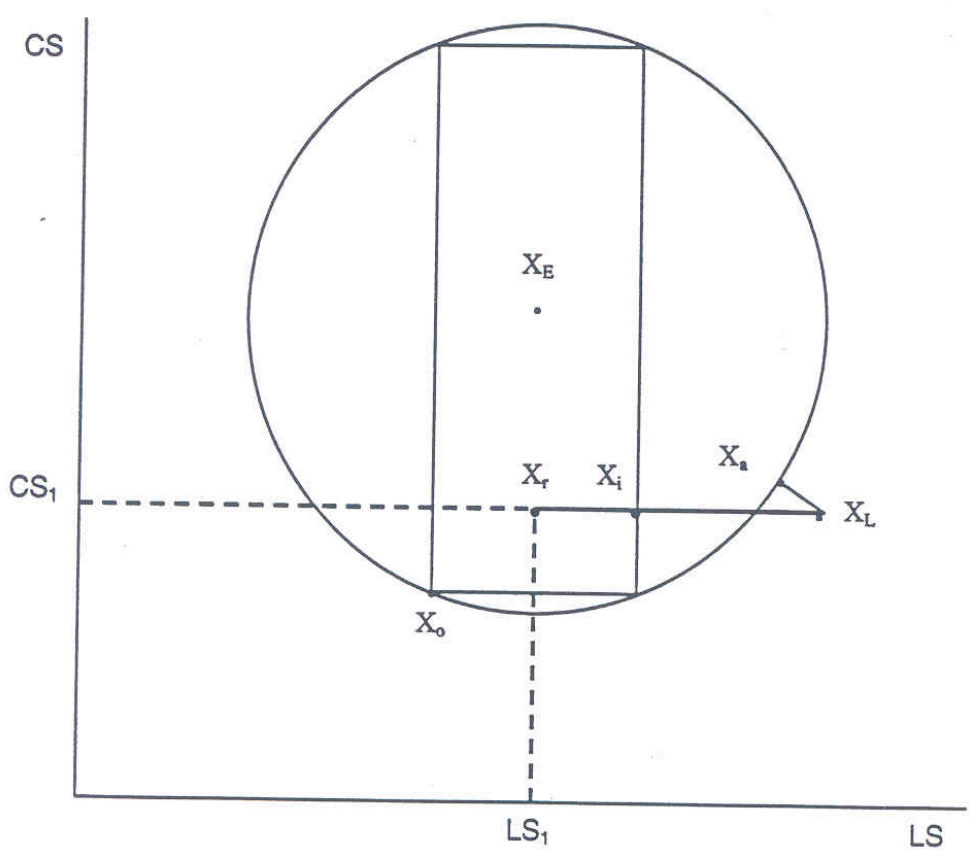

Figure 1. Determination of Central (CS) and Local (LS) Spending 